\title{
THE PRIVATE INTERNATIONAL LAW OF THE NETHERLANDS
}

\author{
J. OFFERHAUS \\ Of the Dutch Bar, Amsterdam \\ (Continued from the December number.)
}

Torts. Torts are governed by the law of the place where they have occurred. The security of individuals and property within the limits of each territory demand this. On the other hand, when a person within a certain territory performs an act, which the local law does not forbid, his immunity ought to be recognized also abroad. Such freedom from liability was recognized by the court of Amsterdam with respect to a seizure made abroad, the seizure being legal according to foreign law, but illegal according to Dutch law. ${ }^{75}$ But the act of a bookkeeper, who had collected money without authority by means of a forged receipt, was regarded. as a tort, in accordance with the law of the place where the act had been done. ${ }^{78}$ The same rule prevails on the subject of collision of ships, ${ }^{77}$ so far as the provisions of the International Treaty of September 23d, I9ro, are not applicable. ${ }^{78}$ When a collision occurs on the high seas between ships of different nationality, many systems are possible. A Dutch decision applies the lex fori, $^{79}$ and with this Kosters ${ }^{80}$ agrees.

\section{LAW CONCERNING RELATIONSHIP}

Marriage. In general there is a clear distinction in the law of marriage between form and capacity. Many theories are possible in respect to the selection of the law governing marriage and the power to marry; the personal law of the husband governs matrimonial matters in general, and the personal law of each of the parties, their power to marry. Let us first examine the condition of persons coming from countries like the United States, which have not joined the Treaty of the Hague. ${ }^{81}$ We shall thereafter briefly touch upon the

${ }^{75}$ Ct. Amsterdam (Jan. 3I, I916) W. 9925; Trib. 's Hertogenborch (June 27, r9I7), (I917) N. J. 1205.

${ }^{78} \mathrm{Ct}$. Amsterdam (June 5, Igr4), (IgI4) N. J. III5; cf. also Trib. Amsterdam (May 10, I918) W. I0327, (rg18) N. J. 821.

"Trib. Dordrecht (Oct. 25, I916), (1917) N. J. 390; Trib. Rotterdam (Nov. I, I917), (I918) N. J. 952.

"Being in force in Holland according to the law of Jan. II, I9r3, Staatsblad, 26-27.

${ }^{70}$ Trib. Rotterdam (Nov. 6, I895), (1895) Magasijn Van Handelsrecht, 264.

${ }^{80}$ Kosters, 799.

" Treaty of June 12, r902, in force by law of July 24, 1903, Staatsblad, 23I. 
Treaty, which does not differ very much from the law operating outside of the Treaty territory.

Dutchmen abroad and foreigners in Holland are governed by their national law, in respect of their power to marry. As regards Dutchmen this can be deduced from article 138 of the Civil Code, which states that marriages contracted by Dutchmen or by a Dutchman and a foreigner, have no validity if the parties, as far as they have the Dutch nationality, have violated the Dutch provisions concerning the essential operative facts required to constitute a valid marriage. This article prohibits, therefore, the marriage of a Dutchman with a Mohammedan already married, because Dutch law does not permit polygamy.

As regards foreigners also, the power to marry is, generally speaking, governed by their personal law. The recognition of the personal law may clash, however, with the Dutch public policy or good morals, so that capacity for marriage that exists according to the personal law of a foreigner, may not be admitted in the Netherlands. Dutch courts would consider that the prohibition of bigamy, the prohibition of marriage between near relatives, or the want of the free consent of the parties so concerns public policy as to avoid the marriage, even though it is perfectly valid according to the personal law of the parties.

The prohibition of marriage between near relatives would probably be applied in the following manner. When there is an absolute prohibition in the Dutch law, not avoidable by dispensation, such a prohibition should be applied to foreigners; but when dispensation is allowed, this possibility should be extended to foreigners as well as to Dutchmen.

It is an interesting problem whether the Dutch provision, forbidding the marriage of a person convicted of adultery with his accomplice, is applicable to foreigners. ${ }^{82}$ The Dutch legislation on this point seeks to prevent adultery as much as possible. In consequence of this system our courts have decided that this prohibition applies also to foreigners who desire to marry their accomplice in Holland, although their national law does not forbid the marriage. ${ }^{33}$ Jitta doubts whether these decisions are correct. $^{84}$

There is still another curious point of dispute. The Tribunal at Amsterdam is of opinion that the prohibition of article 89 of the Civil Code, just referred to, is only applicable to Dutch husbands or wives, who have been guilty of adultery and now want to marry in Holland. The consequence of this limited application of the Dutch law is that a marriage concluded by a Dutch husband with his accom-

\footnotetext{
Art. 89, Dutch Civil Code.

"Trib. Amsterdam (May 4, I906) W. 8588; Sup. Ct. (April 16, 1908) W. 8718.

3 Jitta, 349.
} 
plice cannot be recognized in Holland, but that the Dutch law has no objection to the recognition of a marriage concluded abroad by a married man who has a foreign nationality, with his Dutch accomplice. $^{85}$ The Court of Appeals reversed this decision, however, holding that the Dutch law revolts against any disturbance of family life by an accomplice of Dutch nationality. Marriages concluded abroad by such accomplices and foreigners cannot be recognized, therefore, as valid in the Netherlands. ${ }^{86}$

Our courts have not passed upon the other prohibitions existing under Dutch law. They would probably refuse to recognize even the validity of a subsequent marriage by a divorced person, because Dutch law forbids such marriages of Dutchmen.

On the contrary, the Dutch authorities and courts sometimes allow marriages to be concluded in the Netherlands, when only their personal law and not the lex fori forbids the marriage. For example, an Italian citizen whose national law forbids his marriage on account of natural impotence ${ }^{87}$ will be allowed to marry in Holland because an equivalent provision is unknown in this country. For the same reason prohibition to marry based upon religious or economical reasons or upon differences of race cannot be recognized in Holland.

As regards the form of celebrating marriages, Dutch law only knows civil marriages, ${ }^{88}$ which, according to the general rules, are governed as to the mode of celebration by the law of the place where they are concluded. In other countries marriage may have a religious character, so that the mode of marrying may be subject also to the provisions of the national law, which are applicable to the citizen even abroad. In the Netherlands foreigners as well as natives can get married only in one way, namely, by appearing before a registrar. This rule is so strict that a clergyman performing any religious ceremony prior to the secular marriage, is liable to penalty. ${ }^{80}$ Our provisions concerning the form of marriages are very strict. Marriages concluded by foreigners in Holland can be annulled on account of non-compliance with the provisions concerning the form of celebration, even when the provisions of both systems of law with regard to the intrinsic validity of the marriage have been observed.

On the other hand, a marriage concluded abroad by a Dutchman in accordance with the law of the place of celebration, is considered to be valid, although the celebration is purely a religious one, or consists solely of mutual consent. ${ }^{90}$ Dutchmen living abroad are submitted, however, by Dutch law to more stringent rules if the Dutch

${ }^{25}$ Trib. Amsterdam (June 26, I914) W. 9767.

${ }^{85}$ Ct. Amsterdam (May 25, I915) W. 9894.

${ }^{37}$ Art. ro7, Italian Civil Code. ${ }^{83}$ Art. 83, Dutch Civil Code.

${ }^{\infty}$ Art. 449, Dutch Penal Code.

${ }^{\infty}$ Trib. Arnhem (Sept. 15, I88r) W. 4748; Trib. The Hague (Dec. 5, IgIr)

W. 9614 ; Ct. The Hague (June 29, 19r4) W. 9668. 
spouse has his domicil in Holland up to the moment of the marriage or has had such domicil there within the last six months; due publication of the marriage must be made at such domicil according to the provisions of the Dutch law. ${ }^{91}$ Formerly the courts were in doubt whether a marriage might be annulled because of a failure to make such a publication, but an amendment to the article above mentioned, adopted in 1906, makes it clear that the marriage cannot be annulled on that ground.

When a Dutchman, married abroad, returns to his native country, it is his duty to have his marriage license registered within a year at his new domicil. The failure to do so does not constitute, however, a ground for annulment. ${ }^{92}$ If the registration has not been effected within a year after his return an order of a court authorizing the same is necessary. ${ }^{93}$

These instances show that the annulment of a marriage, once concluded, will rarely be pronounced. This appears also from the fact that if a Dutchman marrying abroad does not satisfy the conditions required by his personal law for the intrinsic validity of marriage, the marriage is not absolutely void, but can be annulled only through a judicial proceeding. Indeed, the general rule is that a marriage is never ipso facto void, a judicial declaration being always required. ${ }^{94}$ Sometimes there is an infraction of the law, but the court cannot annul the marriage. Such is the case when a person, being of age but. not having reached his thirtieth year, has not attained the required consent of his kinfolks nor a judical decree dispensing with such requirement. ${ }^{95}$

The Treaty of the Hague applies only to subjects of the participating Governments which have ratified it. ${ }^{26}$ Dutch courts are not obliged to apply the treaty to Austrian subjects, because Austria did not ratify the treaty, although it took part in the conference.

The principal rule laid down by the treaty is that the capacity to marry is to be judged according to the personal law. ${ }^{97}$ The Supreme Court applied this provision once when it held that the Registrar was justified in his refusal to celebrate a marriage because the woman, who was a German, could not produce a certificate that she possessed the capacity to marry. She had been unable to obtain such a certificate, because her divorce from her first husband in Holland could not be

\footnotetext{
${ }^{91}$ Art. 138, Dutch Civil Code.

${ }^{22}$ Art. 139, Dutch Civil Code; Ct. Amsterdam (Nov. 4, 1886) W. 5165; Trib. Rotterdam (March 23, I903) W. 8002.

${ }^{93}$ Trib. Almelo (Aug. 27, I89I) W. 6137.

' Art. I40, Civil Code. See also Sup. Ct. (Dec. 7, I877) W. 4I9I; Ct. The Hague (June 29, I9I4) W. 9668; Ct. Amsterdam (May 25, I9I5) W. 9894.

${ }^{85}$ Ct. Amsterdam (Oct. 2I, I9I8) W. 10342.

Sup. Ct. (Feb. 14, 1919) W. 10396, (I919) N. J. 324.

${ }^{\text {s7 }}$ Art. I.
} 
recognized in Germany. The woman was considered, therefore, as still married in Germany, and was thus unable to prove her own capacity to marry again. ${ }^{88}$

Does the term "national law" comprise all kinds of impediments to marriages, including those of public law, such as the German and Belgian provisions requiring the fulfilment of military duties before a marriage can be concluded? Some Dutch registrars have celebrated the marriage of Belgian or German deserters, who could not show any proof of their compliance with military laws, because the "national law" was regarded as referring merely to private law, and this view has been sanctioned by some courts. ${ }^{1}$ The Supreme Court has held, however, that the provision embraces all impediments, even those derived from public law. Foreign deserters are not allowed to marry in Holland, therefore, when their personal law forbids the marriage. ${ }^{2}$

According to the Treaty, the law of the place of celebration may prohibit marriages, valid according to the personal law of the parties, because they are contrary to certain specified provisions of the lex loci.8 A marriage which is void according to the national law of the parties, may be authorized, on the other hand, if the prohibition of the personal law is based exclusively upon considerations of a religious nature, and would conflict, therefore, with the public policy of the state."

Article 5 of the Treaty regulates the form in which marriages may be celebrated and provides that if the marriage has been entered into in the forms prescribed by the lex loci actus, it shall be recognized as lawful everywhere. The national law of the parties must be followed, however, as regards publication. Failure to do so may render the marriage void in the country whose laws have not been observed, but it is valid elsewhere. As the omission of such publication does not.render the marriage void according to Dutch law, this article has no great importance with respect to Dutchmen marrying abroad.

Effect of Marriage on Property of Husband and Wife. The law governing the property rights of husband and wife has been the subject of long and famous disputes. This question is a difficult one, especially in connection with immovables. It is a famosissima quaestio whether the property of husband and wife is to be governed by one law-that is, the domiciliary or the personal law-or whether the im-

${ }^{28}$ Sup. Ct. (Sept. 26, I9I8), (Igr8) N. J. roI6.

${ }^{-\infty}$ Art. I of the Treaty.

1 Trib. 's Hertogenborch (Jan. 4, I9I7) W. Ioroo, (I9I7) N. J. I30; Trib. Dordrecht (Oct. 4, I9I7) W. IaI75, (I9I8) N. J. I07; Trib. Haarlem (Sept. I, I9I8) W. 10329.

${ }^{2}$ Sup. Ct. (Sept. 26, 1918) W. 10315, (1918) N. J. ro15; also Kosters, 394-395.

${ }^{3}$ Art. 2. See Trib. Amsterdam (May 4, I906) W. 8588; Sup. Ct. (April 16, 1908) W. 8718.

Art. 3. 
movables should be subject to the law of the country where they are located. In Holland there is a general opposition to the theory that the lex rei sitae should determine the condition of property brought into marriage. It is felt that a universal assignment should be governed by a single law.

In the absence of a marriage contract, the Dutch courts are very liberal in applying foreign law. The earlier Dutch decisions usually hold that the explicit or the supposed will of the parties controls. ${ }^{\circ}$ This will may be deduced from statements the married couple made to third persons, from their conduct before or after the marriage, orif this does not explain anything-from an impartial examination of the circumstances, such as the nationality or domicil of the husband or the place where the marriage has been celebrated. When the law of the nationality and that of the domicil of the husband coincide, many judges used to apply formerly that law to matrimonial property. Where the husband's personal law differs from that of the parties' domicil, the lex domicili was considered decisive. ${ }^{7}$ Notwithstanding this fact, the Tribunal of Amsterdam has held that the husband's personal law was applicable. ${ }^{8}$ This decision supports the new doctrine, which prefers the personal statute to the system of the parties' autonomy. The new system is a consequence of the idea that rights and duties resulting from the existence of matrimonial property are closely connected with the interests of the whole family and with marital power. The parties have the power to make a marriage contract, but if they do not make use of this power, no conclusion can be drawn with respect to their will. Their will not being expressed, the law governing should be the personal law. When the husband has no nationality at all, the law of the common council of the spouses takes the place of the husband's national law.9 This system has gradually been accepted by the Dutch courts ${ }^{10}$ and is also inserted in the Treaty of the Hague.

When there is a marriage contract, the personal law of each of the spouses governs their capacity to enter into it; the form is determined by the lex loci actus. Such contracts when made by Dutchmen abroad

${ }^{5}$ Ct. Leeuwarden (June 29, I887) W. 5515; Trib. Winschoten (Jan. 19, 19ro) W. gor3; Sup. Ct. (Jan. 6, IgII) W. gra5.

- Ct. 's Hertogenborch (Feb. Ig, 1878) W. $422 \mathrm{I}$; Ct. Leeuwarden, preceding note; Trib. Amsterdam (Nov. I, 1907) W. 8809.

Trib. Winschoten (Jan. 27, 1886, and June r6, 1886) W. 5447; Ct. Amsterdam (Dec. 15,1892 ) W. 6303 , and the decisions of courts of 's Hertogenborch and Leeuwarden, preceding note.

${ }^{8}$ Trib. Amsterdam .(Nov. I, I907) W. 8809.

- E. M. Meyers, in W. P. N. R., 236r.

${ }^{10} \mathrm{Ct}$.'s Hertogenborch (June 27, 1905) W. 8272, and (April 7, I908) W. 8802; Trib. Amsterdam (Nov. 13, 1908) W. 8916; Trib. Rotterdam (March 8, 1909) W. 8953; Ct. Amsterdam (June 6, r919) W. 10444. 
may a a rule be recognized in the Netherlands, but their contents must always be compared with the provisions of the husband's national law, so far as these provisions have an imperative character. For example, the provisions guaranteeing to the wife her earnings, are always determined by the husband's national law.

The courts will not readily admit that marriage contracts made by Dutchmen abroad and referring in general terms to a law other than the personal law of the husband, are to be considered valid. The Tribunal at Rotterdam denied the validity of a "deed of gift" made in England, according to British law, by a Dutch husband to his wife. It was held that inasmuch as no marriage contract had been made, no foreign law could govern matrimonial property, but only the personal law of the husband, which did not recognize deeds of such a nature. ${ }^{11}$ In the same way ambiguous terms and omissions in marriage contracts are to be interpreted according to the husband's personal law: ${ }^{12}$

When a foreigner marries in Holland, even with a Dutch woman, their marriage contract, if made in accordance with the national law, is valid unless it conflicts with Dutch opinion about good morals-a fact which the courts do not readily admit. It is advisable, however, for foreigners to execute their marriage contracts in Holland according to the formalities prescribed by Dutch law, for it is not certain that the judge would approve an instrument under private signature, even though it is sufficient according to the national law.

Article 198 of the Civil Code, forbidding a reference to foreign law in general terms, is applicable only to persons whose matrimonial property is governed by Dutch law, and is intended to prevent an evasion of Dutch law. It is not applicable to foreigners. ${ }^{13}$

Article 207 of the Civil Code provides that marriage contracts adopting another system than that of a legal community of goods, operate against third persons only from the moment that they are entered upon a public register, which is kept at the office of the tribunal within whose jurisdiction the marriage has been celebrated, or in case the marriage took place abroad, where the marriage license was filed. This article does not apply to foreigners married abroad who have established their domicil in Holland. ${ }^{14}$ Third persons have, therefore, no right to assume, from the mere fact that no marriage contract can be found upon the Dutch registers, that none was entered into.

${ }^{11}$ Trib. Rotterdam (March 8, 1909) W. 8953.

${ }^{13}$ Trib: Maastricht (Nov. 9, 187I) W. 3513.

${ }^{13}$ Sup. Ct. (June 24, I8g8) W. 7I4I ; Kosters, 448.

${ }^{14}$ Ct. 's Hertogenborch (April 2I, x914) W. 9595, W. P. N. R. 2320; Sup. Ct. (Jan. 8, 1915) W. 9762. 
A change in the nationality of husband and wife does not cause the new national law to govern their matrimonial property. Such a change would ordinarily result from a change of nationality, but the law governing matrimonial property operates unchanged, during the existence of the marriage. Some legal systems, including the Dutch, forbid any change in the marriage contract during the marriage.

In other countries-so far as the law permits a voluntary change of nationality during marriage-a change in the law governing their matrimonial property is possible only by virtue of a special declaration of the will. It would be wrong to deduce from the simple change of nationality the intention of the parties to submit their property to the new personal law. Although there are no decisions on the point, it seems advisable when the first personal law forbids an alteration of the contract and the later personal law allows it, to apply the new personal law to this extent, that the prohibition should have effect no longer, and husband and wife should be, in accordance with the new law, entitled to change their marriage articles. ${ }^{15}$

The provisions of the Treaty of the Hague relating to matrimonial property agree substantially with the Dutch law. They lay down the general rule that when no marriage contract has been made, movables as well as immovables are governed by the personal law of the husband at the moment of the celebration of the marriage. ${ }^{16}$ The capacity of the parties to make a marriage contract is determined by their personal law, while the intrinsic validity and the legal consequences of the contract depend on the husband's national law. ${ }^{17}$ The national law of the parties determines also whether they can enter into a marriage contract during their marriage or change an existing contract. ${ }^{18}$ A change in the nationality of either husband or wife or of both has no influence upon their property, ${ }^{19}$ whether a marriage contract exists or not. The power to enter into a marriage contract or to alter an existing contract is determined by the personal law of the spouses at the time such contract or such alteration is made.

With regard to the form of marriage contracts; the Treaty adopts the rule that the form is to be determined according to the laws of the place where the contract was made. This rule has an optional character, and the contract is valid also if it conforms to the national law of each of the parties at the time of the marriage or of the making of the deed, if this should occur during marriage. ${ }^{20}$ When the national law of the spouses is not the same, the form of the lex loci must be satisfied. If the personal law of one of the parties positively requires its provisions regarding form to be followed, even though this contract

${ }^{15}$ Kosters, 454, following French jurisprudence.

${ }^{16}$ Art. 2.

${ }^{18}$ Art. 4

${ }^{17}$ Arts. 3, 5 .

${ }^{\infty}$ Art. 6.

${ }^{10}$ Art. 2. 
is made abroad, such provisions must be followed. ${ }^{21}$ This constitutes an explicit infraction of the general rule, "locus regit actum."

Divorce and separation from bed and board. It is advisable to distinguish the conditions submitted to the Hague Convention ${ }^{75}$ from those standing apart from that Convention.

Beginning with the latter, to which belong the relations between the United States and the Netherlands, we notice that the law governing Dutchmen abroad and that which governs foreigners in Holland are different. A divorce of Dutchmen and a separation from bed and board (which we will include under the term "divorce") can be pronounced by a foreign court. Such a decree may be recognized in Holland, provided, however, the foreign court had jurisdiction and that Dutch laws concerning the conditions of divorce have been observed. This is a strict application of the statutum personale, which in regard to Dutchmen is to be found in article $6, W$ et $A . B$.

The same principle is not applied, however, to foreigners seeking a divorce in Holland. On grounds of public policy all persons residing within Dutch territory, either foreigners or Dutchmen, are treated alike. The courts accordingly apply the lex fori, not only with respect to the question whether a divorce is permissible at all, but also with respect to the causes for divorce. ${ }^{78}$ If Dutch law prohibits a divorce, it cannot be pronounced, although it is permitted by the personal law; on the contrary, if it is permitted by Dutch law, the divorce may be pronounced, notwithstanding a prohibition by the national law. In our opinion the Dutch courts have gone too far in the direction of applying the lex fori, and it would have been better if the personal law had been recognized either exclusively or in conjunction with the lex fori. Attention should be called, however, to a decision of a Court of Appeal, holding that no divorce is possible for a cause which the national law does not admit, because the lex fori cannot call into existence a situation prohibited by the national law. ${ }^{7 t}$

While there are few cases of interest involving the substantive law of divorce, many questions have arisen in respect to jurisdiction. It is a general rule that Dutch authorities have jurisdiction in regard to foreigners, when there is a court which is competent, ratione loci. Dutch courts may likewise recognize foreign decrees granting a divorce to Dutchmen, provided that the foreign court was competent according to its own law and applied Dutch law in accordance with the Dutch views concerning public policy and good morals.

According to Dutch law the district court of the husband's domicil ${ }^{78}$ is competent to grant a divorce, both as regards Dutchmen and for-

\footnotetext{
"Art. 6, par. 2.

${ }^{75}$ Treaty of June I2th, 1902, approved by Dutch law of July 24th, I903, and ratified by the Crown.

${ }^{70}$ Sup. Ct. (Dec. I3, I907) W. 8636.

${ }^{77} \mathrm{Ct}$. Arnhem (Dec. 23, I903) W. 8043.

${ }^{78}$ Art. 262, Dutch Civil Code.
} 
eigners. ${ }^{79}$ The courts are incompetent when the husband has his domicil abroad. ${ }^{80}$ In this case the court should dismiss the petition of its own accord, without a request from one of the parties. ${ }^{81}$ Simple residence on the defendant's part or domicil on the plaintiff's part do not confer jurisdiction upon the Dutch courts. This condition of our law is very unfortunate for the woman whose husband has moved to another country after the cause for divorce has arisen. The wife may, of course, always sue before the jurisdiction of the husband's new domicil abroad. But there are some difficulties to be overcome. In the first place, the foreign court must be competent according to its own law, and secondly, the decree rendered must be proper for recognition in the Netherlands, as outlined above. ${ }^{82}$ Article 7 of the Hague Convention requires the recognition of such a decree as regards Convention territory.

When the cause for divorce is malicious desertion, Dutch law confers jurisdiction upon the court of the last common domicil of husband and wife. ${ }^{83}$ No competent judge is available when the last common domicil lies abroad. If the deserting husband returns to Holland and re-establishes his domicil in this country-provided it be apart from his wife-the court of his actual domicil has jurisdiction. ${ }^{84}$

It might be suggested that when a husband leaves Holland with the intention of escaping a justifiable suit for divorce, Dutch courts should be competent on account of the husband's acting in fraud of the law, but the courts hold otherwise. Dutch courts have rarely admitted the principle that the prevention of fraus legis is a positive rule of private international law.

All decrees for the dissolution of a marriage by divorce, or by a separation from bed and board for five years, must be entered upon a public register, and until such registration the marriage is not dissolved.85 Formerly our law required this inscription to be made upon the register at the domicil of the spouses, that is, the husband's domicil. Whenever the husband had removed to another country, great difficulty arose because of the failure of the law to specify a particular register for this case. Marriages which could not be entered in any register remained, therefore, unaffected. Only when the cause of the divorce was malicious desertion was the register of the last common domicil considered the right one. ${ }^{86}$

Trib. Zutphen (Nor. 27, 1902) W. 7871.

${ }^{\infty}$ Ct. Amsterdam (May 25, 1900) W. 7498; Ct. The Hague (Nov. 6, 1907) W. 8620; Sup. Ct. (Jan. 23, 1908) W. 8656.

"Trib. Amsterdam (Oct. I3, I905) W. 84I5; Ct. The Hague (May I, Ig06)

W. roor7; Trib. Amsterdam (Nov. I, 19:8), (I9I9) N. J. 403.

${ }^{2}$ Ct. The Hague (Feb. 7, 1916) W. 9938.

* Art. 266, Dutch Civil Code.

sup. Ct. (May 28, I897) W. 6980; Ct. The Hague (June 26, I902) W. 9393.

${ }^{85}$ Art. 276, Dutch Civil Code.

* Ct. Leeuwarden (Oct. 2, I913) W. 9532. 
This defect in our law was corrected by the Act of March 25, 1915, altering the text of article 276 of the Civil Code. Since that date the registration has to be made in the place where the marriage was celebrated, or, when concluded abroad, at The Hague. In this way registration is always possible and the decree of dissolution has the desired result. The new provision is applicable, however, only to marriages dissolved by Dutch courts, not to divorces pronounced abroad, even though between Dutch parties. Those divorces are governed by the law of the place where the dissolution was pronounced. This consequence is reasonable, because article 276 of the Civil Code is merely a provision about form, so that the lex loci actus is decisive as to the question whether the divorce ought to be registered and how this ought to be done.

The law applicable to divorce, so far as Holland is concerned in its relation to most of the other European states, is to be found in the provisions of the Hague Convention. In the first place, the treaty states that the question whether a divorce can be pronounced, as well as the grounds for which such a decree can be rendered, is to be determined both by the personal law of the spouses at the moment the suit is brought, and by the lex fori. The conditions of both laws must be satisfied. The courts of the country where the suit is brought are allowed, however, to dispense with the application of the lex fori and to be content with the observance of the personal law. ${ }^{87}$ This provision is of no consequence in the Netherlands, because in this country the observance of both the lex fori and the personal law is required. ${ }^{88}$ This system of the necessary observance of two laws has been mitigated in Article 2 of the Convention to this extent, that although a cause of divorce is required according to both laws, it is not necessary that this cause should be the same. It is sufficient that $a$ cause for divorce exists under each law. ${ }^{89}$

The treaty also gives rules about jurisdiction. The suit for divorce may be brought before the court which is competent according to the personal law of husband and wife, as well as before that of the parties' domicil. ${ }^{20}$ Our courts hold that this provision contains entirely new rules about jurisdiction, which take the place of the national provisions. This is true not only as regards foreigners suing in the Netherlands, but also as regards Dutchmen, insofar as the stipulations of the Treaty apply, for the juridical condition of the latter should not be worse than that of foreigners. In case of a change of nationality after the cause for divorce has arisen, the court of the last domicil of the spouses is deemed by our courts to be competent. ${ }^{91}$

\footnotetext{
${ }^{87}$ Art 3, Dutch Civil Code.

${ }^{8} \mathrm{Ct}$. The Hague (June 26, 1902) W. 9393.

This article was applied in the decision mentioned in the foregoing note.

Art. 5, Dutch Civil Code.

${ }^{91}$ Trib. Utrecht (Oct. 24, 1902) W. 944r; Ct. The Hague (June 9, 1913) W. 9522; Trib. Breda (March 26, 1918), (1918) N. J. 788.
} 
The treaty deals also with the effect of divorce decrees within the Convention territory. Provided that the provisions of the treaty relating to divorce have been observed, the recognition of judgments is compulsory. ${ }^{92}$ Another condition which must be fulfilled is, that when the decree is rendered by default, the defendant must have been served with process according to the rules required by his personal law for the recognition of foreign judgments. Our courts have decided in this connection the following interesting case.

A foreign court divorced two Dutch persons, although the marriage had not been concluded according to Dutch law and therefore should have been annulled. Was the divorce to be recognized in the Netherlands, with the effect that the marriage before the granting of the divorce was to be accepted as valid? It was held that the Convention applies only to marriages which are considered as valid in the Convention territory. When this condition is lacking on account of the nullity of the marriage, a divorce pronounced later on need not be recognized in Holland and the annulment of the marriage can still be pronounced. ${ }^{93}$

Legitimacy and Legitimation. One of the most important subjects at the present time is certainly the question concerning the statutum personale and the personal law with respect to paternity and descent. This is also the case with regard to the status of a legitimate child. The personal law determines the conditions required for the claim of legitimacy, the evidence to be furnished, the question whom plaintiff ought to summon, and the time within which this must be done. There are no Dutch decisions on this point, but the correctness of these principles is beyond any doubt in view of articles 6 and 9, Wet $A$. $B$.

A suit for the establishment of legitimacy, which the Dutch law allows, may be brought also by a foreigner staying in Holland, who may ask a Dutch court to determine his status according to his personal law. Dutch courts have jurisdiction as regards Dutchmen residing in Holland who contend that they are the legitimate descendants of Dutchmen living abroad. Dutch courts, of course, have no jurisdiction concerning foreigners who have their domicil in a foreign country.

The reverse of the child's claim of legitimacy is the reputed father's denial of the child's legal status. Foreigners living in Holland may appeal to Dutch courts in this matter, both the conditions requisite for the establishment of the petitioner's claim, and the means of evidence by which they are to be proved, being governed by their personal law. Moreover, the child residing iu Holland will be protected in Holland in accordance with the local provisions concerning the status of legitimate and illegitimate children. A child can not lose its status, therefore, on account of its national law, when the domiciliary law does not admit

\footnotetext{
"Art. 7, Dutch Civil Code.

Trib. The Hague (Dec. 5, 19Ir) W. $96 \mathrm{r} 4$.
} 
the father's claim. Jitta ${ }^{94}$ objects even to the recognition in the Netherlands of a decree rendered abroad by a court of the child's nationality denying the child's legitimacy, if the illegitimacy could not have been established in Holland. $\mathrm{He}$ is of opinion that the jurisdiction of the domicil; which would maintain the legitimacy, is to be preferred to the national jurisdiction, invoked by the father to deny it. It seems reasonable, however, that when a foreign child has been pronounced illegitimate by a foreign court, such a judgment should be recognized in Holland as a valid decision, for there would appear no sufficient reason for the Dutch courts to interfere with the question and to deny the validity of such a decree.

Before discussing the subject of legitimation, some words must be said about the recognition of natural and illegitimate children, a process which, according to Dutch law, produces certain civil relations between the child and the parent, without, however, putting recognized children on the same footing as legitimate children.

The conditions and consequences of recognition are governed by the personal law of the child and the parent, when they both have one common nationality. When both parents are of a different nationality, an interesting conflict may arise on account of the provision of article 339 of the Dutch Civil Code, requiring the mother's consent to a recognition by the father. The object of this article is to protect the mother, who ought to have an opportunity to judge whether the intended relation between the father and the child will or will not be in the interest of the child and herself. When a Dutch father recognizes a child, born of a foreign mother, it will not be necessary to submit the whole matter of recognition to the Dutch law; but the necessity of the mother's consent will depend upon the mother's personal law. The consequence of this principle is, that when the mother is a Portuguese or a Belgian woman, her consent is not required, because the laws of those countries do not provide for it..$^{95}$ In the same way, the child's personal law should be decisive, if the child's own consent is necessary for its recognition by the father.

When the child has another nationality than its parents, the personal law of the recognizing parent governs the conditions necessary for the recognition, but the child's own personal law controls the questions whether and how the child may itself object to such recognition.

In this connection we may refer to the law of 1892 , regulating Dutch nationality. This law says that a child which has not been recognized either by its mother or by its father, has the Dutch nationality when

\footnotetext{
2 Jitta, 393.

${ }^{2}$ Trib. Amsterdam (June 26, I9II) W. 9422; Ct. Amsterdam (May 2, I9I3)

W. 9557; Trib. Amsterdam (Dec. 24, 1912); Ct. Amsterdam (June 27, I913) W. 9438 .
} 
born in the Netherlands. If it should be recognized later by a foreigner, it will obtain that foreigner's nationality, with retroactive effect.

There is only one exception to be made to the application. of the foreign personal law. Children born of adulterous or incestuous relations cannot be recognized by Dutch law, and this provision applies to foreigners recognizing a natural child in Holland. To hold that the provisions of the Dutch law are inapplicable to foreigners in Holland would oppose good morals. It is questionable, however, if public policy in our country denies validity to the recognition of such children when it has taken place in another country, and it seems probable that such recognition would be considered as good. Jitta ${ }^{96}$ and Kosters ${ }^{97}$ are of opinion that there is not an absolute impediment to such a recognition, because innocent children should not be deprived of their rights obtained abroad.

A claim to the legal recognition of natural paternity cannot be entertained by the Dutch courts, but a claim on account of maternity is admitted. Dutchmen staying abroad should on this point observe their national law, lest the judgments pronounced in this regard might not be recognized, in the Netherlands. Foreigners in Holland are absolutely subject to Dutch law on this point, for Dutch good morals are opposed to a claim of status on account of paternity, made by foreign natural children in reliance upon their personal law, which differs so profoundly from Dutch law, and would be contrary to its spirit, which seeks to secure tranquillity of family life. But if the foreign law, contrary to the Dutch law, allows such an action on account of paternity, a decree of a foreign court establishing such relationship, as well as the status created thereby, may be recognized in the Netherlands. ${ }^{.8}$

A child may obtain a legitimate status also by legitimation. This institution is governed also as to its intrinsic validity and its consequences by the personal law, as regards legitimation by subsequent marriage. The parents' national law determines whether their marriage entitles their children, born out of wedlock; to become legitimate. When the national law of two foreigners marrying in the Netherlands does not know such a legitimation, the children remain illegitimate, although the children's personal law-if different-allows the contrary. If the child's personal law does not know such a legitimation, although the law of the parents admits it, the legitimation can not be forced upon the child. In such a case the child may rely upon its own law, and object to the legitimation. ${ }^{90}$

The Dutch provision that legitimation is only possible after previous recognition raises a difficult problem in private international law. Does

$\begin{array}{ll}{ }^{20} \text { Jitta, 398. } & \text { Kosters, } 538 . \\ { }^{28} \text { Kosters, 540. } & \text { Kosters, 550. }\end{array}$ 
such recognition belong to the essentials of legitimation, so that it is a necessary condition whenever the personal law requires it? Or does the previous recognition concern the form of legal acts, so that it has to be performed always in the Netherlands, although a similar provision does not exist in the personal law? The better answer would appear to be that the recognition is an essential part of legitimation, and is subject, therefore, to the personal law, especially since a Dutch child will acquire the status of legitimacy only after being recognized.

Foreigners, in order to be legitimated in the Netherlands, need not be previously recognized, if this is not required by their personal law. Dutchmen staying abroad, on the other hand, have to recognize their child before legitimation, because the legitimation can only then be considered as valid in Holland. When a foreigner has legitimated his child abroad without previous recognition, such legitimation will be regarded as valid in Holland. Those children will enjoy, therefore, the same rights with respect to movables and immovables situated in Holland as are possessed by legitimate children.

According to Dutch law a child can also become legitimated by socalled letters of legitimation, issued by the Queen upon the advice of the Supreme Court. Those marks of favor may as a rule be given only to Dutchmen, but in some particular cases such legitimation is extended also to foreigners residing in Holland, if it conforms with the provisions of their personal law. Dutchmen can receive such letters only from the native authorities; no validity can be attached to letters issued by foreign authorities.

When the parents and the child have different nationalities, the personal law of the parents is decisive as to the question whether such letters may be given. If the parents have different nationality, the father's personal law is applicable. Legitimation by means of such letters makes the child legitimate from the date of the parents' marriage.

Adoption. It is difficult to say very much about adoption, because this institution is unknown to Dutch law, and Dutch courts never have been asked to pass upon the question. In principle the national law should be decisive, but considerations of public policy may oppose. As a matter of fact no adoption proceedings can take place in the Netherlands, nor can Dutchmen be validly adopted abroad, because such adoption would be contrary to Dutch law. Where a foreigner has been adopted abroad, it may be recognized as legal in Holland, so long as he remains a foreigner. ${ }^{1}$ But when the foreigner has become a naturalized Dutchman, we are inclined to think that the previous adoption will become invalid; because no Dutchman can ever acquire an adoptive relationship towards other people.

Parental pozer: The relation of parents and minor children is determined by their personal law, because it belongs to the status of 
persons, so far as the exercise of the parental power and the rights arising therefrom with regard to persons and property are concerned. ${ }^{2}$

When the nationality of parents and children is the same, no difficulty arises. Foreign parents staying in the Netherlands are then allowed to exercise their parental power according to their common personal law, provided that they do not act in contravention of Dutch notions of public policy. Their right of punishing the children is restricted, therefore, to the measure admitted in Holland. ${ }^{3}$ As regards parental power Holland is thus more liberal than, for example, Great Britain, where the personal relation of parents and children staying in England is governed by English law. ${ }^{4}$

In the Netherlands the father or mother exercising the parental power enjoys the right of usufruct in the property of their minor children. Opinions differed formerly regarding the question whether the personal law decides this point or the law of the country where the property is situated, at least with respect to foreign immovables. According to the modern view the personal law is decisive, because the essential point is not the provisions governing the ownership of immovables, but the personal relation of the parent and the child.

In the Netherlands the parental power may be declared lost or forfeited if it is in the child's interest and if there is a court which is competent, ratione loci. ${ }^{5}$ In such a case the court of the parent's domicil has jurisdiction. A judgment of this kind may be based upon a cause which is not recognized by the personal law. Indeed, all of these rules concern the protection of children in the Netherlands and are applicable, therefore, to all parents residing within Dutch territory.

If the parent has abandoned his domicil in Holland, the courts of the last domicil there have jurisdiction. Dutchmen may be deprived, therefore, of their parental powers by their national judge, even after they have left their native country. Of course, this does not exclude the possibility of a decree by a foreign court, declaring the parental power to be lost after their settling in the foreign country, and the decision of such a court would certainly be recognized in Holland, provided that the personal law has been observed.

No cases have arisen respecting the governing law where there is a difference between the nationality of the parents and that of the children. Kosters ${ }^{6}$ is of opinion that the personal law of the parents is decisive, because the rights arising from the parental power tend to protect the family life and because the child owes its status to its parents. This view is preferable to the opinion that the parental power especially tends to the child's protection. The personal law is applicable also to the parents' right of usufruct in the property of their children situated in Holland or abroad.

= Trib. The Hague (June 2g, 1915) W. P. N. R. 2380.

Jitta, 410.

'Dicey, Conflict of Laws (I896) 492.

' Ct. Amsterdam (June 2I, 1915) W. 9869.

${ }^{8}$ Kosters, 560-56r. 
Guardianship of minors. Guardianship is governed by the national law of the interested parties. ${ }^{7}$ If the nationality of the parents and of the child or that of the guardian and of the child differ, the question as to which will control depends in each case upon the nature of guardianship. If the guardianship is to be considered as a consequence of the relation of parents and children, it being a continuation of a previous parental power, the personal law of the parents is decisive. This law determines whether and in what manner the parental power passes into guardianship; whether it is necessary to appoint a coguardian, and the rights and duties of the guardian or co-guardian. This doctrine is more in accordance with sound theory than that of an old judgment, which selected the personal law of the child. ${ }^{8}$ If the guardianship is exercised by a third person and not by a parent, and has been called into existence on behalf of the child without the cooperation of the parents, the personal law of the ward, in whose favor the guardian is appointed, is decisive.

In Holland a foreigner may be appointed guardian of a Dutch minor. Indeed, our law provides that when the guardian resides abroad, a ward acquires the domicil of his co-guardian. The purpose of this provision is to prevent the withdrawal of Dutch wards from their national jurisdiction. In order that such wards may retain a domicil in Holland in regard to all matters concerning guardianship, the law requires the co-guardian to be an inhabitant of the Dutch Kingdom. ${ }^{\circ}$ From these rules it is manifest that the legislature had no intention of exempting foreigners from appointment as guardians. ${ }^{10}$ Kosters, nevertheless, is of the opinion that foreigners are obliged to accept a Dutch guardianship to the same extent as Dutchmen are, whenever they are connected with the Netherlands by a permanent domicil.11

When a foreigner has accepted the guardianship of a Dutch ward the Dutch law determines the obligations incumbent upon him. ${ }^{\mathbf{1 2}}$

In the absence of a legal or testamentary guardian, the county judge appoints a guardian. The competent judge is the judge of the ward's domicil. When the ward is domiciled abroad, the judge of his last domicil in Holland may appoint a guardian, and if he never had domicil in this country, such appointment may be made by the judge at Amsterdam. ${ }^{13}$ These rules, however, do not affect the consular laws.

If a person is appointed abroad as a guardian of Dutch minors, such appointment will be recognized in Holland, provided that the Dutch

? Trib. The Hague (June 29, 1915) W. P. N. R. 2380.

${ }^{8}$ Trib. Maastricht (Dec. 20, I860) W. 2254.

'Sup. Ct. (Jan. I9, IgII) W. gI3I.

${ }^{10}$ Trib. Maastricht (Dec. 28, I843) W. 473, and (Dec. 20, 1860) W. 2254.

iI Kosters, 570.

${ }^{12}$ Trib. Amsterdam (March 15, 187I), (1872) Rechtsgeleerd Bijblad, 303 (this periodical is no longer published).

${ }^{13}$ Art. 4I7, Dutch Civil Code. 
law concerning guardianship has been observed. This condition is not fulfilled if the office of co-guardian is unknown in the foreign country, so that only a guardian has been appointed for the Dutch ward. A guardianship of this kind is not valid in the Netherlands, ${ }^{14}$ it becoming necessary to establish a new guardianship in our country.

Dutch courts have jurisdiction to appoint guardians for foreign minors residing in the Netherlands, even though the parents live abroad, provided that the child's personal law is observed. The rights and duties of guardianship for foreigners, as well as the administration of such guardianship are governed by the ward's personal law. Our courts hold, accordingly, that the personal law determines whether a guardian needs the court's authorization for the sale or the pledge of the ward's property (such authorization being required in the Netherlands), and if such authorization is required, from what court consent may be obtained. ${ }^{15}$ The same law determines also the necessity of such an authorization with respect to immovables situated in the Netherlands and belonging to a foreign ward. From the foregoing it is seen, therefore, that the personal law prevails over that of the lex rei sitae.

Guardianship is in part controlled by the rules of the Treaty of The Hague of June 12, I902.10 This treaty also is based upon the rule of the personal law, the protection of minors being considered as the chief consideration. The public policy of the country where the minor resides only requires the appointment of a guardian; it does not prohibit the exercise of such guardianship according to foreign law. The administration by the guardian is subject, therefore, to the personal law, irrespective of the situs of the property; unless, perhaps, the law of the country where the immovable is located should subject such property to a special property régime, for example, the institutions of fiefs, primogeniture, or homesteading. As these are unknown in Dutch law, the above qualification has significance only if the immovable is situated in some other country in which the particular institution exists.

Article 8 of the treaty imposes upon the authorities of the state within whose territory there is a foreign minor for whom it is necessary to create a guardianship, the duty of informing the authorities of the state of which the minor is a subject, of this situation, and the authorities so notified should at the earliest possible moment indicate to the authorities giving such notice whether a guardianship has been or will be created there. If this has not been and will not be done, a guardian may be appointed at the actual residence of the child, according to the local law. ${ }^{17}$ This guardianship will be replaced, however,

\footnotetext{
${ }^{14}$ See Trib.'s Hertogenborch (Dec. 2, I864) W. 2648 (guardianship of a Dutch child in the State of New York).

${ }^{25}$ Trib. Middelburg (March 31, I847) W. 1009; Cty. Ct. Brielle (Oct. 25, 1880)

W. 4583; Cty. Ct. Enschedé (Dec. 24, 1909) W. 9028.

${ }^{16}$ Approved by the law of July 24, 1903, and ratified by the Crown.

${ }^{27}$ Art. 3, Dutch Civil Code.
} 
by a national guardianship as soon as the authorities of the native country act in the matter. This agrees with one of our decisions, holding that a Dutch court has the authority to dismiss a guardian, appointed in Belgium for a Dutch minor residing in that country. ${ }^{18}$

\section{SUCCESSION}

In general. In the course of years two systems have contended for mastery. One considers the inheritance as a universality of goods, and therefore submits all movables and immovables to the single law of the testator's origin. The other holds that immovables are governed by the law of the country where they are situated. The last mentioned system has maintained itself in Dutch jurisprudence. Our Supreme Court still held in 1907 that the immovable part of an inheritance was governed by the lex rei sitae. It based its decision upon article $7, W e t$ $A$. B. which applies this law to immovables, holding that there is no reason to exempt from the operation of this rule immovable property belonging to a succession. ${ }^{19}$

The Supreme Court has never decided by what law the movable part of an inheritance is to be controlled. The court is likely to select the law of the testator's last domicil on the ground that his movables are deemed, in legal contemplation, to be at that place. ${ }^{20}$ No conclusion can be reached, however, in view of the Court's silence, especially because both the text-writers and the decisions of other courts maintain the doctrine that the inheritance as a whole is to be governed by one law. The possibility exists that the Supreme Court will revert to this theory some day, the more so, because it applied this system on two former occasions, preferring at that time the testator's latest domicil. . $^{21}$ Recent judgments of the Supreme Court and of the court at Rotterdam apply the lex rei sitae to immovables, and the personal law of the testator to the remaining part of the succession.22

$\mathrm{Jitta}^{23}$ and Kosters ${ }^{24}$ also favor the doctrine of the universality of property and the application of the personal law. The latter is preferred because Dutch law tends to apply such law as regards capacity. Moreover, article $7, W$ et $A$. $B$. regulates only the condition of immovables considered separately, but says nothing about the acquisition of immovable property by succession.

According to Dutch law, the individuality of the deceased is continued by his heirs. Their rights and duties are to be governed, therefore, by the law determining the testator's status. Moreover, it is

\footnotetext{
${ }^{18}$ Cty. Ct. Amsterdam (Oct. 22, I906) W. 8458.

${ }^{10}$ Sup. Ct. (April 5, 1907) W. 8524; Ct. Arnherh (April 27, 19ro) W. 9052.

${ }^{20}$ Kosters, 62x.

${ }^{21}$ Sup. Ct. (Feb. 15, I86r) W. 2278, and (Nov. 17, 1887) W. 5502.

${ }^{2}$ Sup. Ct. (June 23, I9I3) W. P. N. R. 2279; Trib. Rotterdam (May 4, 1914) W. P. N. R. 2340.

${ }^{23}$ Jitta, 542.

24 Kosters, 622.
} 
probable that, so far as testamentary succession is concerned, the testator, in disposing of his property, had his personal law in view and. intended the application of that law.

The personal law of the testator governs his own capacity to make a will and the capacity of the heirs to acquire property by way of intestate or testamentary succession, the right of accepting or repudiating the inheritance, the transmission of the assets and debts, the duty of collation, the separation of the inheritance, and the capacity of the executors of a will..$^{25}$ The nationality of the heirs is of no consequence. This system, however, was considered many years ago as too bold by some courts, in the case where the testator was a foreigner and the heir a Dutchman. They applied Dutch law to the consequences of an acceptance under benefit of inventory (without liability of incurring debts beyond assets), made by a Dutch heir, though the testator was a foreigner. ${ }^{28}$

Dutch law will preclude the application of the personal law, of course, to the inheritance of a foreigner, deceased in Holland, if such application is opposed to public policy. The personal law may deprive a person of his right of inheriting for a cause not admitted by Dutch law, for example, because of civil death or ecclesiastical ordination. Persons excluded trom the inheritance on the above grounds are capable of inheriting in Holland.

Exceptions of this kind based upon public policy are possible also in relation to immovables. Institutions foreign to Dutch law cannot be created with respect to Dutch immovables owned by a foreigner by virtue of his personal law. For example, no rights of primogeniture, of homestead, or heirship rights (Anerbenrecht) can be created in this way.

The foregoing general rules are applied also to particular matters of succession, for example, to the question how an inheritance is to be acquired, or whether a separate acceptance is necessary. According to Dutch jurisprudence, the heirs get possession of the property at the moment of the testator's death, all his property and claims being acquired without any particular act of acceptance. ${ }^{2 \pi}$ A court passing on the inheritance of a Dutchman, will apply these rules, but cannot prevent, of course, the heirs living in other countries from obtaining possession of property situated abroad, according to the rules of the lex rei sitae. Such an acquisition may not be recognized, however, in the Netherlands, for the heirs residing in Holland are entitled to the inheritance, even though their rights are interfered with by foreign claimants. ${ }^{28}$

\footnotetext{
${ }^{*}$ Trib. Amsterdam (Dec. 28, 1914) W. 9850 .

Trib. Amsterdam (Oct. 18, I859) W. 2139; Trib. Rotterdam (March 9, 1859), (1860) Rechtsgeleerd Bijblad, 372.

${ }^{27}$ Arts. 880, 1002, Dutch Civil Code. $\quad{ }^{39}$ Art. 88I.
} 
The acquisition of an inheritance belonging to a foreigner occurs according to his personal law. Questions about repudiation are governed by the same law. Some difficulty may arise from article rro3 of the Dutch Civil Code. According to this provision, a repudiation must be made by a declaration before the court within whose jurisdiction the property was located at the time of the testator's death. But this law does not say who is competent to receive such a declaration if the Dutchman dies in a foreign country. It is reasonable to assume that article IIO3 only concerns inheritances becoming vacant in the Netherlands, so that the above mentioned declaration is not required under these circumstances. Jitta ${ }^{29}$ suggests that the court of the testator's last domicil in Holland has jurisdiction. The question has not been decided, however, by our courts.

Foreigners in Holland, intending to repudiate a Dutch inheritance, as well as Dutch heirs, should observe the provisions of article IIO3.

Testamentary. In the Netherlands the capacity of foreigners to dispose of their property by a will is judged according to the testator's personal law. This law will apply also to the capacity of the heirs to take under a will, because the Dutch law in regulating this matter had in view the protection of the testator's property. It must yield, however, to the Dutch provisions which exclude some particular categories of persons from succession. An heir who is incapable according to Dutch law, is, therefore, excluded, although his personal law allows him to acquire property under the will.

The right to dispose of one's property is rather severely restricted in Holland by the rules concerning the legal reserve on behalf of the nearest relations. These rules do not establish, however, a public policy, so that a more liberal right of disposition according to the personal law of the testator will be recognized in Holland. Where a Dutchman had become naturalized in another country and had made use thereafter of the privilege conferred by his new personal law, the Supreme Court applied this new law, because the extent of the legal reserve was to be judged according to the testator's law at the time of his death. ${ }^{30}$

As regards the form of wills, we have an article in the Dutch Civil Code which has given rise to much controversy. Article 992 authorizes Dutch subjects to make a will in another country only in an "authentic" form and with due observance of the usual formalities prescribed for such acts by the Dutch law. A foreign court, passing on the validity of a Dutchman's will, may have to solve the question, therefore, whether the provision of the above-mentioned article concerns only the "form" of legal acts, so as to call for the application of the rule locus regit actum, or whether it constitutes a restriction with

$\Rightarrow$ Jitta, 567.

"st Sup. Ct. (June 27, 1913) W. P. N. R. 2279. 
respect to "capacity." In the latter event the personal law ought to be observed even abroad, under penalty of annulment of the will. If the will by a Dutch subject abroad is not "authentic," it will have to be pronounced invalid by the Dutch courts. Although article 992 deals with the form of acts, it states plainly that the provision is to apply to Dutchmen abroad. Whether a Dutchman complies with the article 992, by making an holographic will abroad and entrusting it to a notary public for safe-keeping, a mode of execution which would give the will validity if made in Holland, is doubtful. A decision rendered in 1886 held such a will to be invalid. A will made under private signature and written by the testator himself was not deemed to acquire the prescribed authenticity by being deposited with a notary public, though its validity would be undoubted if so executed in the Netherlands. ${ }^{31}$ Later the same court changed its view and admitted that kind of a will to probate as a valid authentic document. ${ }^{32}$

It seems preferable to say that the act is authentic if the forms which the lex loci requires for such an act have been observed, so that the validity of the will would depend on the observance of that law. When this law considers the custody of an holographic will as conferring upon it an authentic character, the instrument should be recognized also in the Netherlands. ${ }^{33}$ The validity of a will made by a foreigner in Holland will be recognized, on the other hand, if its form satisfies the requirements of the law of the place of execution. ${ }^{34}$

The interpretation of legal clauses, deeds, and wills is so closely connected with the judge's personal views, based upon the law, that no other law than the lex fori can be applied. Indeed all foreign provisions concerning interpretation, if useful to our courts, are interpreted by a Dutch judge in conformity with his own laws. Moreover, Dutch law states in regard to the subject of contracts and wills, that explicit terms are decisive; so that no application by means of interpretation is allowed when the words are plain. These provisions are applicable to all wills of foreigners, although the succession itself is governed by a foreign law.

Other provisions relating to interpretation, however, have another character, for example, articles 924 and 925 of the Dutch Civil Code, containing particular rules about the meaning of "the nearest relations," "the poor" and so on, when used in wills. These provisions form an integral whole with the general provisions of the law, and will follow Dutchmen, therefore, abroad. When the personal law of a foreign testator is applied by a Dutch court, it enforces all provisions similar to those mentioned above. This is the meaning of the decision that the

\footnotetext{
"Trib. Amsterdam (July 6, I886), (I886) Paleis van Justitie, Nos. 49-50 (this periodical is no longer published).

"Trib. Amsterdam (June 28, I904) W. P. N. R. I807.

Kosters, 645; J. Offerhaus, Nederlandsch internationaal bewijsrecht 48-50.

uitta, 150 .
} 
word rinunziare, occurring in an Italian instrument, must be interpreted according to Italian law, in view of the fact that the Italian Civil Code attaches a very particular notion to the repudiation of an inheritance. $^{35}$

Jurisdiction for the determination of claims against the state belongs to the courts of the place where the testator had his domicil at the time of his death..$^{38}$ This rule is applicable to the succession of all testators who died domiciled in Holland, irrespective of their foreign nationality. Article 126 of the Code of Civil Procedure does not confer jurisdiction upon any courts as regards foreign successions abroad, even though the testator is a Dutchman. The consequence of this silence is that there is, generally speaking, no competent judge in the last mentioned cases. ${ }^{37}$

It is possible, however, that a Dutch court has' jurisdiction in respect to property belonging to a foreign inheritance, for example, that of a Dutchman who died in a foreign country, if a suit is brought by a creditor of the estate against an heir residing in the Netherlands. In this event the Dutch court's jurisdiction is based upon the defendant's domicil.s8

The distribution of the property is made according to the personal law of the testator, so far as no intervention of the authorities is required. Such an intervention is sometimes necessary, however, according to Dutch law. When the heirs cannot dispose of their goods freely (for example, if they are minors), articles III7 and IIzo of the Dutch Civil Code require for the distribution of the property the approval of the county judge.

Is this rule applicable also when a foreigner is an heir? Some people answer this question in the negative, because the said provision concerns the personal statute and is not applicable, therefore, to foreigners. ${ }^{30}$ Others are of opinion that the law was meant to protect those who cannot co-operate in the distribution and that such protection should be extended, therefore, to Dutchmen and foreigners alike. ${ }^{40}$ The Supreme Court has held that when there are minor heirs living in Holland, of Dutch or foreign nationality, the jurisdiction of the Dutch county judge extends to the distribution of the property left by a Dutchman who died abroad. A foreign court has jurisdiction in this .

\footnotetext{
${ }^{\star}$ Ct. Amsterdam (Dec. 2, I918), (I919) N. J. 403, W. 10433, W. P. N. R. 2584

Art. ז26, sec. 12, Code of Civil Procedure.

Trib. The Hague (Nov. 9, I877) W. 4180; Sup. Ct. (Apr. 2r, 19rI) W. 9174; Trib. Haarlem (Jan. 2, 1917) W. P. N. R. 2470; Ct. Amsterdam (Dec. 2, 1918) (Igrg) N. J. 403, W. 10433, W. P. N. R. 2584

${ }^{28}$ Decision of $\mathrm{Ct}$. Amsterdam, mentioned in the foregoing note.

${ }^{5}$ Cty. Ct. Goor (Oct. 22, 1892) W. 6267; Cty. Ct. Medemblik (Jan. 20, 1893) W. 6513.

${ }^{10}$ Trib. Almelo (Nov. 8, 1892) W. 6267; Kosters, 652.
} 
case, generally speaking, but the executors may ask the assistance of the Dutch county judge of their domicil, on behalf of the minor heirs living in Holland.41

The second example is the following. According to Dutch law, the heirs may demand an order of the court, directing the sale of the immovables belonging to an undivided inheritance, if the property is situated in Holland. This is done to promote the liquidation of the estate and to facilitate the payment of debts. Our courts tend to hold that Dutch law determines the question whether such an order should be given, or whether the heirs should be allowed to effect a sale of their own accord, without regard to the personal law of the deceased in this respect. $^{42}$ Kosters, ${ }^{43}$ on the other hand, would adhere to the principle that the personal law controls. According to our decisions, the court competent to authorize such a sale is that of the place where the testator had his domicil when he died. Dutch courts are incompetent, therefore, when the succession took place in a foreign country.4 In only one case was it held that the local court had jurisdiction. ${ }^{45}$ It seems probable, however, that any Dutch court would assume jurisdiction if an application for the sale of the property should be made by all heirs.

\section{PROCEDURE}

Jurisdiction of Courts. The written law fails to indicate when Dutch courts have jurisdiction in matters of private international law. The codes, especially the Code of Civil Procedure, only regulate the competence of Dutch courts, ratione loci. As regards foreigners, Dutch courts assume jurisdiction, however, if they live in Holland and there is a judge who is competent, ratione loci. ${ }^{48}$ One of the most prominent principles of Dutch procedure is that the court of the defendant's domicil, and, in default of a domicil, the court of his actual residence, is competent to hear and determine any personal action against him. This principle is also applicable to a defendant who is a foreigner. In this way every plaintiff-either a Dutchman or a foreigner-may summon before a Dutch court a defendant who is a foreigner, provided the latter has his domicil or actual residence in the Netherlands. ${ }^{47}$

\footnotetext{
4 Sup. Ct. (Feb. 13, 1893) W. 6301.

${ }^{2}$ Trib. Goes (May 19, 184I) W. 206; Trib. The Hague (Dec. 3, 1909) W. 9128.

Kosters, 654

"Trib. Breda (Nov. 18, I890) W. 595I; Trib. Haarlem (Sept. 10, 1892)

W. P. N. R. II87; Ct. Amsterdam (Sept. 30, 1892) W. P. N. R. II90.

${ }^{4}$ Trib. The Hague (Dec. 3, 1909) W. 9128.

* Trib. The Hague (March I9, I918) W. I0339; Ct. Amsterdam (Dec. 2, I918), (Ig19) N. J. 403, W. I0433, W. P. N. R. 2584

"Trib. Rotterdam (Feb. 15, I915), (I915) N. J. 1063; Trib. Breda (May 22, 1917), (1917) N. J. 594; Trib. The Hague (June 27, 1918) W. 10367.
} 
The preliminary questions whether there is a competent judge and whether the defendant can be considered as having a domicil or a residence in Holland, are determined exclusively by the lex fori. ${ }^{48}$ There is no jurisdiction, therefore, if the lex fori does not admit the judge's competence, ratione loci.

$\mathrm{Jitta}^{49}$ maintains that the jurisdiction of Dutch courts is based either upon their authority with regard to the defendant or upon their authority with respect to the subject-matter. Authority in regard to the defendant means, that the courts in each country are under a duty to protect all persons living within its territory against unjust demands and to compel them to comply with their just obligations. In these cases the Dutch court's jurisdiction is clearly well-founded. But what are the rules of jurisdiction, when the defendant has his residence abroad? Article I27 of the Code of Civil Procedure provides that foreigners, even when domiciled in another country, may be sued before Dutch courts in respect of contracts concluded with Dutchmen. Before the year I838 article 14 of the French Civil Code prevailed in the Netherlands, which allowed French citizens to sue foreigners living outside of French territory, before French courts. When the French code was repealed in the Netherlands, the legislature desired that Dutchmen should not be placed in a disadvantageous position as conpared with Frenchmen. Article I27 was intended, therefore, to confer upon them the privilege of suing foreigners before their own courts, when these courts would be without jurisdiction according to the ordinary rules. One of the consequences of this rule-which refers only to contracts concluded with Dutchmen-is, that the privilege does not exist if the contract was originally concluded between two foreigners, the claim being subsequently assigned to a Dutchman. ${ }^{50}$

The Supreme Court interprets article I27 as being closely connected with article 9, Wet $A$. B., which puts foreigners upon a footing of equality with Dutchmen as regards civil law. The "civil law" is held to include the right to sue in a court which has jurisdiction as to lawsuits between Dutchmen. ${ }^{51}$ From this it follows that a foreigner may sue another foreigner residing abroad before a Dutch court. Dutch courts have jurisdiction, therefore, in suits between two foreigners, provided that there is a judge who is competent, ratione loci.

A limitation upon the authority of our courts with respect to this subject-matter is to be found in article $3^{\mathrm{I}} 4$ of the Code of Civil Procedure. This article provides that in commercial matters the courts of the place where the contract was concluded, where the goods were delivered, and where the payment is due, are competent. Our courts

\footnotetext{
${ }^{43}$ Trib. Breda (Nov. 28, 1916), (r917) N. J. 140; Trib. The Hague (March 19, I9I8) W. I0339.

0 Jitta, I64.

${ }^{50}$ Sup. Ct. (May 29, I9r4), (rgr4) N. J. 780.

${ }^{4}$ Sup. Ct. (June 2r, I90I) W. 76rI.
} 
have concluded therefrom that these different courts are competent also in matters of private international law, even when the parties are foreigners and do not reside in the Netherlands. ${ }^{52}$

Dutch courts are not competent, however, with respect to every dispute which may arise in the Netherlands. In the matter of an attachment in Holland against a debtor who has his domicil abroad, it has been held by the Supreme Court that the law gives to the tribunal of the debtor's domicil exclusive jurisdiction. There is no competent judge, therefore, when the debtor resides abroad, though the attachment has been made in the Netherlands. ${ }^{53}$

A well-known provision of our law reads that the court of the plaintiff's domicil is competent when the defendant has not an actual residence in Holland. A plaintiff, though a foreigner, having a domicil in Holland, may sue the defendant at his (the plaintiff's) Dutch domicil, regardless of the place where the defendant may live. But a foreigner who resides abroad has not such power, unless there is authority and jurisdiction over the subject-matter as outlined above.

When the question relates to a breach of contract which has no connection with this country, it can be based upon the domicil of one of the parties, in accordance with the general rules already noticed.

During the war a Dutch vessel was sunk by German soldiers at Mechlin (Belgium). The owner sued the German Empire before the court at Rotterdam, which rendered a judgment against the former Empire by default. ${ }^{54}$ The criticism of this judgment showed that most of the lawyers were of opinion that the law of nations did not authorize a suit against a foreign power in a civil case. The judgment of the tribunal of Rotterdam was annulled by the Court of Appeal.55 The legislature put an end to the controversy by adding a new article to the $W$ et $A$. $B$. which provides: "The jurisdiction of courts and the execution of judgments and authentic documents is limited by the exceptions recognized in the law of nations."

The way in which an action is to be brought, especially by corporations. Every group of persons who are acting together in social life as a corporation according to the laws of the country where their activity has its, central point, is recognized as such in the Netherlands and may be sued as such. ${ }^{57}$ A difference of opinion exists as to whether

${ }^{52}$ Sup. Ct. (June 21, I90I) W. 76rr; Trib. Amsterdam (Dec. 6, I9Iz) W. 9510, (I913) N. J. 199.

${ }^{\infty}$ Sup. Ct. (Dec. 24, I915) W. 9933.

Trib. Rotterdam (Sept. 25, 1916) W. 10022, (1917) N. J. 13.

${ }^{*}$ Ct. The Hague (March 23, 1917) W. IoI7o, (I918) N. J. 38; see also Trib. Rotterdam (April 2, I9I7), (IgI7) N. J. 434, and Trib. Maastricht (Nov. 23, 1916), (1917) N. J. I2.

${ }^{60}$ Act of April 26th, Igr7 Staatsblad, No. 303; see Prof. E. M. Meyers, W. P. N. R. 2457 .

${ }^{87} \mathrm{Jitta}, 600$. 
such a corporation has to appear in the mode prescribed by its own laws or according to the lex fori. Jitta and some of our courts consider it reasonable that a corporation should act in the manner that is customary in its own country. ${ }^{58}$ Other courts hold, on the other hand, that the way in which foreign companies have to proceed in a Dutch lawsuit is governed by the lex fori. ${ }^{59}$

Summoning foreigners. Dutchmen and foreigners living in the Netherlands must be served either personally or at their domicil. When the defendant is a person living abroad, the summons is handed to the public prosecutor of the court having jurisdiction in the case, and this officer has to forward a copy to the Minister for Foreign Affairs. ${ }^{62}$ The time between the service of the summons and the appearance before court is eight days. This time is extended to a month when the defendant lives in one of the countries adjoining the Netherlands, and may reach a limit of eight months, according to the distance at which the defendant lives from Holland. For defendants in the United States at least five months must be allowed.

Limitation of actions. The -most important question is whether the law governing the subject-matter itself determines the period within which an action must be brought, or whether it is the law of the place where the suit has been instituted. ${ }^{63}$ When an action which is pending in the Netherlands is barred according to the law of the country whose law governs the subject-matter itself, while it is not yet barred by the statutes of the lex fori, the Dutch court will enforce the action. ${ }^{\text {os }}$ But when the Dutch statute of limitations is shorter, it will prevail over the foreign statute, because, as $\mathrm{Jitta}^{\mathrm{BS}}$ says, social peace considered from an international point of view is thereby promoted.

Evidence. Dutch law is wavering between the Anglo-American system, which classes the law of evidence among the provisions that are subject to the lex fori, and the Italian law, which holds that the matters of evidence in conflict of laws are determined by the law of the place where the act is performed. ${ }^{63}$

It is quite certain that the lex fori controls the forms. The means of evidence, however, tend to sustain existing relations, and should be taken, therefore, from the conditions surrounding the facts to be proved. Witnesses and documents especially derive their value from

Ct. The Hague (Nov. 3, 1908) W. 8779; Sup. Ct. (April 30, 1909) W. 8868; Trib. Rotterdam (Dec. I6, I9I6) W. P. N. R. 2478, (I9I7) N..J. 435.

${ }^{3} \mathrm{Ct}$ 's Hertogenborch (Aug. 5, I899) W. 5926; Trib. Rotterdam (May 19, 1909) W. 9009; Trib. The Hague (March 16, I911) W. 9160; Trib. Amsterdam (May 29, 1914) W. 9683 .

- Asser, Schetz van het intermationaal privaatrecht, 107.

* To the latter effect, see Ct. The Hague (March I5, I9ro) W. 8984

Ct. The Hague (March 23, 1903) W. 7945.

¿ Jitta, 340.

* Art ro, Preliminary Dispositions, Italian Civil Code. 
the fact that they refer to circumstances occurring while the parties were still on friendly terms. These means of evidence are prepared by the parties with a view of availing themselves thereof if a lawsuit should occur. Some decisions relating to authentic instruments are in accordance with these rules, while the ancient rule, locus regit actum, has also a great influence upon this matter. An instrument is only authentic if it was drawn up by or in the presence of a public officer who is entitled to act as such. The authority of these persons, ${ }^{67}$ as well as their quality ${ }^{88}$ is always judged according to the law of the place where the matter in question has its origin and where the instrument was drawn up, not by the lex fori.

The same idea is to be found in the following case, which held that the date of a contract of pledge, concluded in Germany, could not be challenged by third persons residing in the Netherlands, although article I9I7 of the Dutch Civil Code, which requires the date to be proved by an undeniable fact (such as the registration of the deed or a party's death), had not been complied with. Article I9I7 was deemed inapplicable, because the parties had relied upon the validity of the contract of pledge from the day it was drawn up, according to German law. ${ }^{68}$

These arguments apply also to oral contracts. According to Dutch law, no parol evidence by witnesses is allowed in respect to contracts, the value of which exceeds 300 guilders. ${ }^{70}$ Is this rule also applicable to contracts concluded abroad, when the law under the government of which the contract was called into existence, does not thus restrict the proof of contracts? Our courts answer the question in the negative, because the parties in making their contract must have relied upon the fact that the contract may be proved by oral testimony and refrained on that account to reduce it into writing. They were not obliged to reckon with the provisions of a law which did not govern their judicial relations. ${ }^{\text {11 }}$

Another article provides that no weight can be attached to oral testimony unless it is supported by at least two witnesses. ${ }^{72} \mathrm{Jitta}^{73}$ considers this article so stringent that Dutch courts would not be allowed even in international matters to take into consideration the testimony of one witness. It seems more reasonable to approve the view adopted by the tribunal at Amsterdam to the effect that the law governing the contract controls also in this regard. ${ }^{74}$

\footnotetext{
"Trib. Almelo (Dec. 2, 1896) W. 6925; Trib. Rotterdam (June 24, 1914), (I915) N. J. 362.

${ }^{8}$ Sup. Ct. (Jan. 28, I88I) W. 4600 and Sup. Ct. (June 27, I88I) W. 4673.

${ }^{\circ} \mathrm{Ct}$. Amsterdam and Sup. Ct. (March 24, 1905) W. 8198.

${ }^{70}$ Art. 1933, Dutch Civil Code.

"Trib. Rotterdam (Oct. 13, 1914), (1914) N. J. 312; Trib. The Hague (March 19, 19r8) W. 10339.

T2 Art. I942, Dutch Civil Code. $\quad{ }^{73} \mathrm{Jitta}, 6 \mathbf{} 5$.

${ }^{74}$ Trib. Amsterdam (March 3, 1911) W. 9208.
} 
Some provisions of Dutch law are very closely connected with the essential principles of Dutch procedure, so that a deviation from those principles is not allowed. We may mention by way of illustration the rules concerning the incompetency of witnesses (for example, descendants in the direct line, etc.). As to these matters the requirements of due procedure are deemed paramount in comparison with the private interests of the parties. In respect to the challenging of witnesses opinions differ. ${ }^{7}$ The courts have not passed on the question.

\section{EFFECT OF FOREIGN JUDGMENTS}

In the exceptional cases in which foreign judgments are enforced, an immediate execution is given after permission to that effect has been obtained from the president of the tribunal within whose jurisdiction the execution is to take place. The most famous example is article 724 of the Commercial Code, which enables despatches, stated and approved abroad, immediately to be executed in the Netherlands. Other examples are to be found in the treaty on the Rhine, the Railway Convention of Berne and the Treaty of the Hague concerning divorce. ${ }^{76}$ Article Ig of the Treaty of the Hague on civil procedure provides for the enforcement within all participating countries of judgments for costs without a re-examination of the foreign proceedings. The treaty requires that the judgment, the enforcement of which is sought, be authentic, that no appeal from it be possible, and that certain other conditions be fuifilled.77

Article 43I of the Code of Civil Procedure controls if the foreign court, in deciding a question, derived its competence from its own law. It may occur, however, that the court derived its competence, not from the law, but from a particular clause of the parties' contract, in which it was agreed that any controversies arising from the contract should be determined by a particular judge. The amount so found to be due can be enforced by the Dutch courts. Some courts consider such an action, however, as that enforcement of a foreign judgment which is forbidden by Dutch law, and require that the matter be tried over again. $^{78}$ Others are of the opinion that such a foreign judgment settles only the amount due by virtue of the contract, unliquidated before, and that the plaintiff seeks, therefore, to enforce only what the other party owes under the contract. ${ }^{79}$

The latter system has become the settled law in respect to foreign judgments on arbitration. The arbitrators indicated in the contract, in

J Jitta, 615; Kosters, 225; Offerhaus, op. cit. note 33, at p. II2.

${ }^{78}$ Art. 7. $\quad{ }^{\pi 7}$ See Jitta, 170; Kosters, 214

${ }^{7}$ Trib. Amsterdam (Nov. 25, 1914) W. 8260; Trib. Rotterdam (April 21, 1915), (I9I5) N. J. 839. 
giving their decision, are generally deemed to fix the content of the obligation, so that their judgment becomes, as it were, a part of the contract. The successful party is allowed to enforce, therefore, in the Dutch courts the amount found to be due. ${ }^{80}$

Our courts also appear to apply article 43I, which speaks only of the enforcement of foreign judgments, when the foreign judgment is invoked as res judicata, especially in regard to judgments based upon contracts. $^{81}$ The foreign judgment gives no guarantee, therefore, that a new suit may not be brought before a Dutch court. Kosters adheres to this conclusion, and denies that foreign judgments requiring the performance of contractual obligations are res judicata in Holland. In cases, however, in which the foreign court alone had jurisdiction, and even in those cases in which the foreign judgment is not regarded as being in conflict with Dutch notions of public policy, he would allow the defence of res judicata. ${ }^{82}$

Article $43^{\mathrm{I}}$ is not applied, however, to foreign judgments not requiring execution. For example, a foreign decree of bankruptcy or a decree appointing a guardian may be recognized in the Netherlands. ${ }^{83}$ As in all other cases, such decrees will not be recognized if a stringent policy or the good morals of Holland would be violated thereby. So when the status of a Dutchman is changed by a foreign court, such a judgment can only be recognized in Holland if the Dutch law concerning status has been observed. ${ }^{84}$

An interesting evolution may be observed in recent years with respect to foreign judgments, which is characterized by an increasing trust in the justice of judgments rendered abroad. It would be desirable if this progress would go so far as to lead to the enforcement of foreign judgments and their recognition as res judicatae.

\footnotetext{
${ }^{7}$ Ct. Amsterdam (March 13, I9Ix) W. 9227; Trib. Rotterdam (Feb. I7, I915) (I9I5) N. J. 844; Trib. Haarlem (Feb. 18, r9I9), (r9r9) N. J. 283.

${ }^{\infty}$ Ct. Amsterdam (June 26, 1885) W. 5257; Ct. The Hague (April 17, 1895) W. 6725; Trib. Amsterdam (Dec. 24, 1908) W. 8935; Trib. Rotterdam (April 22, I915), (I9I5) N. J. 84r; Trib. Rotterdam (Nov. I8, r915) W. 9968, (r916) N. J. 285 ; Sup. Ct. (Dec. 8, 1916) W. 10054, (rg17) N. J. 29; Trib. Amsterdam (Nov. 9, 1917), (1918) N. J. 108; Ct. Amsterdam (March I, I9I8), (1918) N. J. I085; Sup. Ct. (Dec. 6, Igr8), (I9I9) N. J. r29.

\& Sup. Ct. (Feb. I, I895) W. 6626; Trib. Middelburg (March 28, I900) W. 7527; Trib. Almelo (June 26, I907) W. 8607; Trib. Amsterdam (April 4, r910), (I9r3) N. J. 485.

${ }^{2}$ Kosters, $219 \mathrm{ff}$.

Sup. Ct. (June 2, I876) W. 3997; Trib. Rotterdam (April 14, Ig13), (I913) N. J. 697; Ct Amsterdam (April 24, 1914), (1915) N. J. 789; Trib. Amsterdam (Jan 8, 1915), (1915) N. J. 205; Sup. Ct. (Nov. 5, 1915) W. 9938, (1916) N. J. 12; Sup. Ct. (Nov. 24, I916) W. 10098, (19I7) N. J. 5; Sup. Ct. (Feb. 23, I9I7), (I9I7) N. J. 347.

${ }^{81}$ See the decisions mentioned in the foregoing note.
} 